\title{
ERRATUM
}

Open Access

\section{Erratum to: One-step multicomponent synthesis of chiral oxazolinyl-zinc complexes}

Mei Luo ${ }^{1 *}$, Jing Cheng Zhang ${ }^{1}$, Wen Min Pang ${ }^{2}$ and King Kuok Hii ${ }^{*}$

\section{Erratum to: Chem Central J (2017) 11:81}

\section{DOI 10.1186/s13065-017-0305-1}

After the publication of this work [1] it was noticed that in the legend for scheme 5: '(left 11, right 12)' was accidentally included and should be removed. The drawing for scheme 6 is incorrect and needs to be replaced with the correct version.

We apologise for these errors.

The original article was corrected.

\section{Author details}

${ }^{1}$ College of Chemistry and Chemical Engineering, Hefei University of Technology, Hefei 230009, People's Republic of China. ${ }^{2}$ Department of Chemistry, University of Science and Technology of China, Hefei 230009, People's Republic of China. ${ }^{3}$ Department of Chemistry, Imperial College London, Exhibition Road, South Kensington, London SW7 2AZ, UK.

The online version of the original article can be found under doi:10.1186/s13065-017-0305-1.

\section{Publisher's Note}

Springer Nature remains neutral with regard to jurisdictional claims in published maps and institutional affiliations.

Received: 25 August 2017 Accepted: 25 August 2017

Published online: 20 September 2017

\section{Reference}

1. Luo M, Zhang JC, Pang WM, Hii KK (2017) One-step multicomponent synthesis of chiral oxazolinyl-zinc complexes. Chem Central J 11:81. doi:10.1186/s13065-017-0305-1

\footnotetext{
*Correspondence: luomei@pku.edu.cn; luomeihuahua@sohu.com; mimi.hii@imperial.ac.uk

${ }^{1}$ College of Chemistry and Chemical Engineering, Hefei University of Technology, Hefei 230009, People's Republic of China

${ }^{3}$ Department of Chemistry, Imperial College London, Exhibition Road,

South Kensington, London SW7 2AZ, UK

Full list of author information is available at the end of the article
} provided you give appropriate credit to the original author(s) and the source, provide a link to the Creative Commons license, and indicate if changes were made. The Creative Commons Public Domain Dedication waiver (http://creativecommons.org/ publicdomain/zero/1.0/) applies to the data made available in this article, unless otherwise stated. 